Geliş Tarihi:

04.02 .2021

Kabul Tarihi:

02.09 .2021

Yayımlanma Tarihi:

20.12.2021
Kaynakça Gösterimi: Düzgün Öncel, B. (2021). How does disability status change time allocation? Evidence from Turkey. İstanbul Ticaret Üniversitesi Sosyal Bilimler Dergisi, 20(42), 1307-1321. doi:10.46928/iticusbe. 874601

\title{
HOW DOES DISABILITY STATUS CHANGE TIME ALLOCATION? EVIDENCE FROM TURKEY
}

Research

Burcu Düzgün Öncel

Sorumlu Yazar (Correspondence)

Marmara Üniversitesi

burcu.duzgun@marmara.edu.tr

Burcu Düzgün-Öncel, 2015 yılından beri Marmara Üniversitesi İktisat Fakültesi'nde Doktor Öğretim Üyesi olarak görev yapmaktadır. Lisans (2006), yüksek lisans (2008) ve doktora (2014) derecelerini Marmara Üniversitesi İngilizce İktisat bölümünden almıştır. Uygulamalı Mikroekonometri, Sağlık Ekonomisi, İşgücü Ekonomisi, Hanehalkı Düzeyinde Kadın İşgücü alanlarında çalışmaları bulunmaktadır. 


\title{
HOW DOES DISABILITY STATUS CHANGE TIME ALLOCATION? EVIDENCE FROM TURKEY
}

\author{
Burcu Düzgün Öncel \\ burcu.duzgun@marmara.edu.tr
}

\begin{abstract}
Disability status is one of the certain elements of labor market condition and economic wellbeing. Likewise, disability also affects time devoted to market and nonmarket activities, since individuals without disabilities will be more productive in market activities and better at carrying household duties. In this respect, this study examines time allocation decisions of disabled and nondisabled individuals in Turkey.

Purpose: Main aim of the study is to investigate how individuals with disabilities allocate their time to market work, nonmarket work, leisure, childcare and other work as compared to their nondisabled counterparts.

Method: This study uses data from Turkish Statistical Institute (TURKSTAT) Time Use Survey 2014. Main focus group is non-student, non-retired individuals who are aged between 25 and 64. Seemingly Unrelated Regression (SUR) is used as the estimation methodology.

Findings: Descriptive evidence show that males spend more time to market work and leisure, whereas females spend more time to nonmarket work, childcare and other work on average. Significant differences between disabled and nondisabled individuals are observed in time devoted to market work and nonmarket work both for males and females. Additionally, Seemingly Unrelated Regression (SUR) results show significant and negative association between disability status and time devoted to market work, and significant and positive association between disability and time allocated to nonmarket work and leisure for both genders. Age and education level also are important correlating factors.
\end{abstract}

Originality: This is the first study in Turkey that investigates patterns of time allocation variation by gender and disability status

Keywords: disability, time use, seemingly unrelated regression

JEL Classification: C31, I10, I30 


\section{ENGELLILIK DURUMU BİREYLERİN ZAMAN KULLANIMINI NASIL DEĞİSTTIRIYOR? TÜRKIYYE ÖRNEĞİ}

\section{ÖZET}

Engellilik durumu, işgücüne katılım ve ekonomik refahın temel belirleyicilerinden biridir. Benzer şekilde, engellilik piyasa ve piyasa dışı faaliyetlere ayrılan zamanı da etkiler, çünkü engelsiz bireyler piyasa faaliyetlerinde daha üretken ve ev işlerini yerine getirmede daha iyi olacaktır.

Amaç: Bu bağlamda, bu çalışma engelli ve engelsiz bireylerin zaman kullanım kararlarını incelemektedir.

Yöntem: Bu çalı̧̧mada, Türkiye İstatistik Kurumu (TÜiK) 2014 Zaman Kullanım Anketi verileri kullanılmaktadır. Ana odak grubu, öğrenci ve emekli olmayan, yaşları 25 ile 64 arasında olan kişilerdir. Tahmin metodolojisi olarak Görünüşte İlişkisiz Regresyon kullanılmaktadır.

Bulgular: Betimleyici sonuçlar ortalama olarak, erkeklerin piyasa işlerine ve boş zamanlarına daha çok zaman harcadıklarını, kadınların ise piyasa dışı çalışma, çocuk bakımı ve diğer işlere daha çok zaman ayırdığını göstermektedir. Hem erkekler hem de kadınlar için piyasa çalışmasına ve piyasa dışı çalışmaya ayrılan zamanda engelli ve engelli olmayan bireyler arasında önemli farklılıklar gözlemlenmektedir. Ek olarak, Görünüşte İlişkisiz Regresyon sonuçları, her iki cinsiyet için de engellilik durumu ile piyasa çalışmasına ayrılan zaman arasında anlamlı ve negatif bir ilişki, piyasa dışı iş ve boş zamana ayrılan zaman arasında anlamlı ve pozitif bir ilişki olduğunu göstermektedir. Yaş ve eğitim düzeyi de anlamlı faktörlerdir.

Özgünlük: $\mathrm{Bu}$, Türkiye'de cinsiyete ve engellilik durumuna göre zaman kullanım kararlarını araştıran ilk çalışmadır.

Anahtar Kelimeler: engellilik, zaman kullanımı, seemingly unrelated regression

JEL Sinıflandırması: C31, I10, I30 


\section{INTRODUCTION}

Individuals with disabilities have disadvantaged positions in labor market compared to their nondisabled counterparts. In this sense, numerous studies present that disability is one of the important determinants of labor force participation and employment (Ali et al., 2011; Baldwin and Johnson, 1994; Duzgun Oncel and Karaoglan, 2020; Gannon, 2009; Kidd et al., 2000; Lindeboom et al.,2016; Schuring et al., 2013). In other words, disability condition is recognized as one of the major health determinants in labor market decisions. Individuals with disabilities encounter with less employment opportunities, work in less paid jobs and end up with lower economic well-being.

Likewise, disability is also an essential determinant in time allocation decisions in labor market and outside the labor market. Although majority of the studies analyze the association between health status and time use (Cai et al., 2014; Gimenez-Nadal and Molina 2014; Gimenez-Nadal and Molina, 2015; Gimenez-Nadal and Ortega-Lapiedra, 2013; Podor and Halliday, 2012), few studies examine the link between disability status and time devoted to daily activities (Leufstadius and Erklund, 2008; Lomax et al.,2004; Oi,1991; Pagan, 2013). Revealing the relationship between disability and time allocation to market work and nonmarket work is important in terms of examining the economic welfare of disabled individuals. Leuftadius and Erklund (2008), Oi (1991) and Pagan (2013) state that disability is a situation that changes time allocation because individuals with disabilities need more leisure to rest, more time to acquire medical care and achieve everyday activities (Leuftadius and Erklund, 2008; Oi, 1991; Pagan,2013). Moreover, time spent on travel including commuting time can be longer. These findings imply that time allocation of individuals with disabilities and their economic well-being will be different than individuals without disabilities.

Using TURKSTAT Time Use Survey 2014, the aim of this study is to examine how individuals with disabilities allocate their time as compared to nondisabled individuals. The time allocation categories are determined by following Aguiar and Hurst (2007). These categories are: market work, nonmarket work, leisure, childcare and other work. Furthermore, by following Pagan (2013), particular attention is given to patterns of time allocation variation by gender and disability status. One of the main reasons of investigating males and females separately is the difference between labor force participation rates and time spent on labor market work (e.g. In 2014 male labor force participation is about 70 percent, while it is only 30 percent for females and average weekly hours spent on market work is 42.14 hours for males and 9.42 hours for females in non-agricultural jobs). Main focus group is non-student, non-retired individuals who are aged between 25 and 64 in order to cover the intertemporal component of time allocation decisions such as education and retirement. As far as it is known, this is the first study that examines the relationship between disability status and time devoted to daily activities in Turkey. The outline of the study is as follows: section two describes the data. Section three describes the methodology of the study. Section four presents the results. Section five concludes. 


\section{DATA}

The individual level sample data used in this study come from 2014 Time Use Survey conducted by TURKSTAT. The survey measures time use in daily activities over a time frame in addition to information on a number of demographic and socio-economic characteristics. Respondents are asked to report all activities over a 24 hour period both in workdays and weekends. Although over and underreporting is possible, the structure of the diaries restrain over-reporting of certain activities and sum of all activities cannot exceed 24 hours (Aguiar and Hurst, 2007; Aguiar and Hurst, 2008). Study focuses on the individuals 25 years of age or over and under 65 years of age who are neither students nor retirees. Children under 15, dependent minors who are aged between 15-24, retired individuals and individuals who are older than 65 are excluded from the sample in order to control the intertemporal component of time allocation decisions such as education and retirement. In other words, excluded sample's decisions could be different in terms of heterogeneity in preferences with respect to time allocation. For instance, distribution of market work for children and for individuals over 65 would not be directly comparable with the working-age population. Study also focuses on the observations that have complete diary reports and who are employed in non-agricultural occupations. Time use estimates are converted to hours per week from minutes per day. The sample data has 5186 males, and 6091 females.

World Health Organization (WHO) defines disability status as an impairment or long term health condition that had lasted or was likely to last for six months or more which restricts the individual in daily activities (WHO, 2021). Literature on disability and labor force outcomes uses WHO's definition. Similar to the literature, individuals with disabilities are identified by using two questions in the survey (Gannon, 2009; Kidd et al., 2000; Pagan, 2013). The first question is "Do you suffer from any chronic, physical or mental illness that exists more than 6 months" If the respondent answers the first question as "Yes" then he/she is asked "Does this chronic problem limit your daily activities?" The answer to this question has three categories: not limits, limits to some extent and severely limits. The responses to this second question allow the disability status to be determined (Pagan, 2013). In this sense, disability status variable with four categories are created; i) non-disabled individuals (individuals who do not report any chronic, physical or mental illnesses), ii) disabled individuals with no limitations in daily activities (individuals report any chronic, physical or mental illnesses and say that these illnesses do not limit them in their daily activities), iii) disabled individuals with some limitations in daily activities (individuals report any chronic, physical or mental illnesses and say that these illnesses limit them to some extent in their daily activities) and iv) disabled individuals with severe limitations in daily activities ( individuals report any chronic, physical or mental illnesses and say that these illnesses limit them severely in their daily activities). Thus, both the existence and the extent of disability is defined.

Mutually exclusive time use categories are defined as $i$ ) market work, ii) non-market work, iii) leisure, iv) childcare, v) other work by following Aguiar and Hurst (2007) and Aguiar and Hurst (2008). Market work includes all time spent on main jobs, other jobs, overtime, working for pay at home, and time spent 
searching for a job. Time allocation to non-market work consists of three sub-categories; i) home and vehicle maintenance (house and furniture construction, painting, repairment, renovation and car restore, repairment, wash), ii) obtaining goods and services (all time spent acquiring and shopping any goods or services excluding medical care and education), iii) other home production (cleaning, doing laundry and dishes, ironing, dusting, vacuuming, indoor cleaning). Leisure is defined as total time spent on watching $\mathrm{TV}$, socializing, exercise and sports, reading, hobbies and other entertainment, food preparation and eating, sleeping and personal care. The category childcare includes time spent for caring for a child, teaching a child and playing with a child. All residual activities such as travel, time spent on education, own medical care, care of other adults and religious/civic activities are included in other work category.

Age has four categories; 25-34,35-44,45-54,44-64. Marital statuses of the respondents are married, single and separated. Educational attainment is defined in the following manner: If the individual is illiterate or literate without being graduated from any school, then she/he is defined in the category of no degree. Primary includes individuals who are graduated from primary school of five years. The individual's educational attainment is defined as secondary if she/he has completed 8 years of primary education. High school education category includes individuals who are graduated from high or vocational high school. Finally, the individual's educational attainment is defined as university if the individual has university or a higher degree. Household structure is also controlled, since time allocation gives differential responses with respect to changes in household size, existence of a child/minor or old individual who needs care in the household, existence of household head and existence of vehicle at home. Household size gives information about the number of individuals living in the household. Dummy for minor defines anyone who is under age 15 or ages between 15-24 and a student (not a head and not a spouse) living with some other adults. Dummy for old care indicates the existence of old individuals (over 65) in the household that needs care. Dummy for household without head defines households without heads. Dummy for vehicle show the presence of a vehicle in the household.

\section{METHODOLOGY}

In the estimated model, the respondent has 24 hours in a day and must decide how much time to be devoted to different activities. The decision of the individual about time allocation yields substitution and complementarity effects between time use activities. Thus, more time individuals allocate to any one activity, the less time will be available for the others (Pagan, 2013). Following Gimenez-Nadal and Molina (2015) and Ozturk and Kose (2019), linear regressions that show time allocation to market work, nonmarket work, leisure, childcare, and other work are estimated by using Seemingly Unrelated Regression (SUR). The estimated equations are as the following:

$$
\begin{aligned}
& m w_{i}=\beta_{m w, 0}+\beta_{m w, 1} D_{i}+\beta_{m w, 2} \boldsymbol{X}_{\boldsymbol{i}}+\beta_{m w, 3} \boldsymbol{Z}_{i}+\varepsilon_{m w, i} \\
& n m w_{i}=\beta_{n m w, 0}+\beta_{n m w, 1} D_{i}+\beta_{n m w, 2} \boldsymbol{X}_{i}+\beta_{n m w, 3} \boldsymbol{Z}_{i}+\varepsilon_{n m w, i}
\end{aligned}
$$


$l e_{i}=\beta_{l e, 0}+\beta_{l e, 1} D_{i}+\beta_{l e, 2} \boldsymbol{X}_{i}+\beta_{l e, 3} \boldsymbol{Z}_{i}+\varepsilon_{l e, i}$

$c c_{i}=\beta_{c c, 0}+\beta_{c c, 1} D_{i}+\beta_{c c, 2} \boldsymbol{X}_{i}+\beta_{c c, 3} \boldsymbol{Z}_{i}+\varepsilon_{c c, i}$

$o w_{i}=\beta_{o w, 0}+\beta_{o w, 1} D_{i}+\beta_{o w, 2} X_{i}+\beta_{o w, 3} Z_{i}+\varepsilon_{o w, i}$

where $m w_{i}$ is market work, $n m w_{i}$ is nonmarket work, $l e_{i}$ is leisure, $c c_{i}$ is childcare and $o w_{i}$ is other work. $D_{i}$ is the variable indicating disability status of individual (e.g. nondisabled, disabled with no limitations, disabled with some limitations, disabled with severe limitations). $\boldsymbol{X}_{\boldsymbol{i}}$ is the vector of socioeconomic and demographic characteristics (e.g. age, marital status, education) and $\boldsymbol{Z}_{i}$ is the vector of household structure (e.g. existence of a minor/child in the household, existence of an old individual who needs care in the household, household size, existence of a vehicle in the household and dummy indicating households without heads). By following Gimenez-Nadal and Molina (2015), correlations in unobserved determinants of the activities are allowed. Further, error terms are assumed to be normally distributed with no constraints on the correlation and are independent across observations. Since time use categories in this study do not have high fraction of zeros, SUR methodology for market work, nonmarket work, leisure, childcare and other work is estimated by using Ordinary Least Squares (OLS).

\section{RESULTS}

Figure 1 shows mean time devoted to five time use categories (i.e market work, nonmarket work, leisure, childcare and other work), according to disability status and age. Column A shows the distribution for males, and column B is for females. The figure displays that males spend more time to market work and leisure, whereas females spend more time to nonmarket work, childcare and other work on average in all age categories. Furthermore, time allocated to market work decreases with disability and age both for males and females. On the other hand, mean weekly hours spent on nonmarket work and leisure increases with degree of disability and age for both genders. Average time devoted to childcare decreases and time devoted to other work increases with degree of disability and age for females, while no pattern is observed for males. 
market work
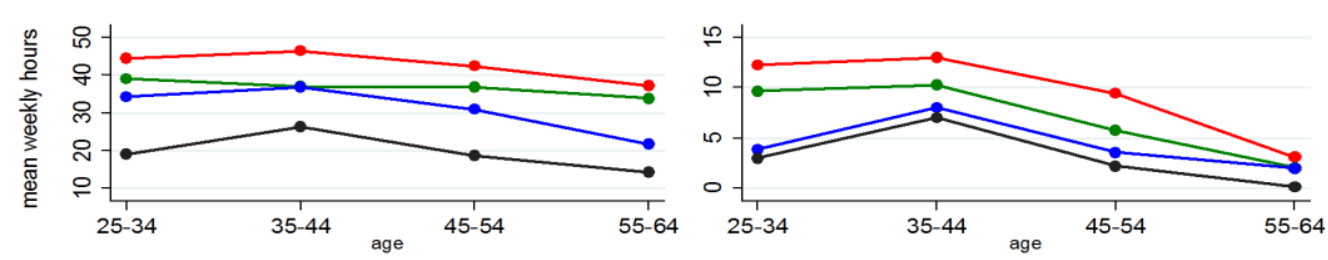

nonmarket work
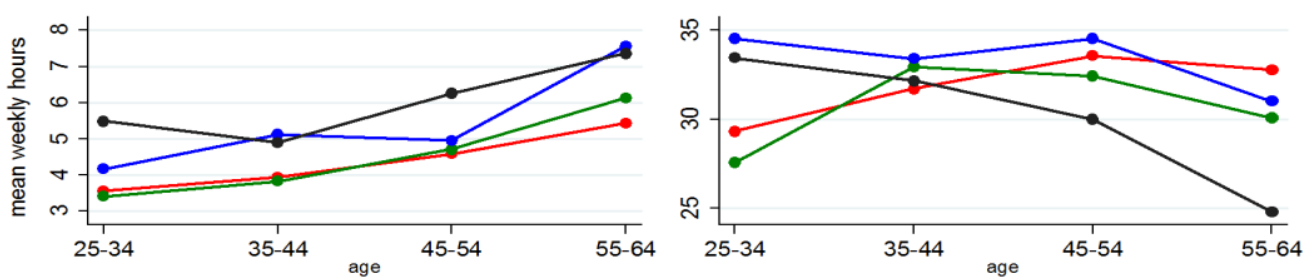

leisure
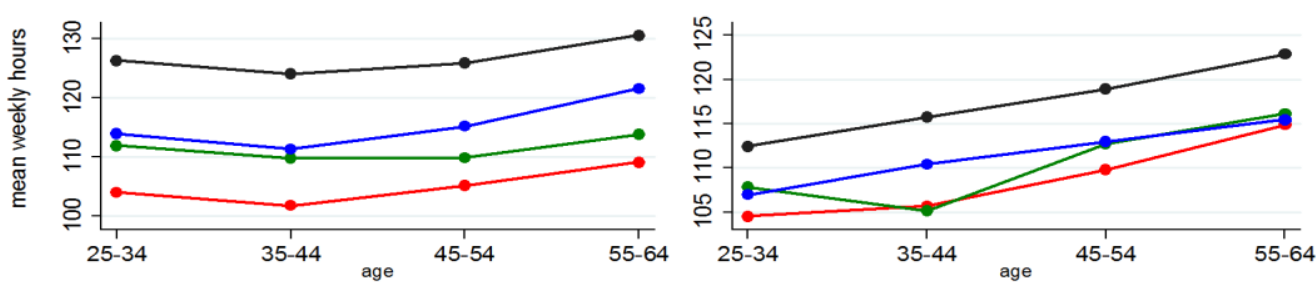

child care
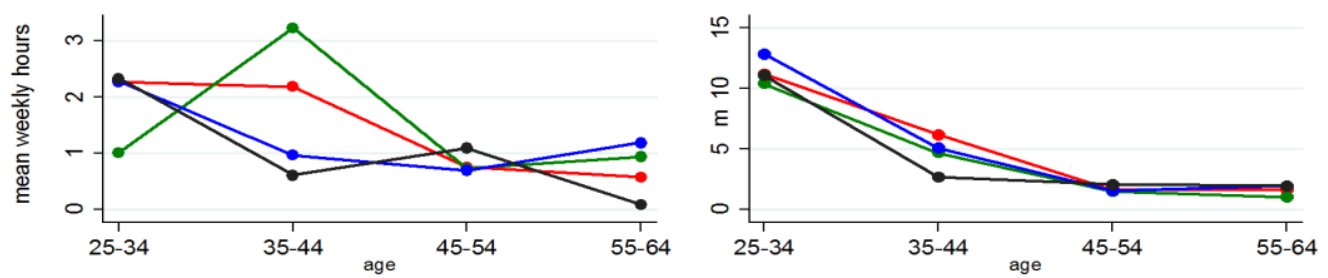

other work
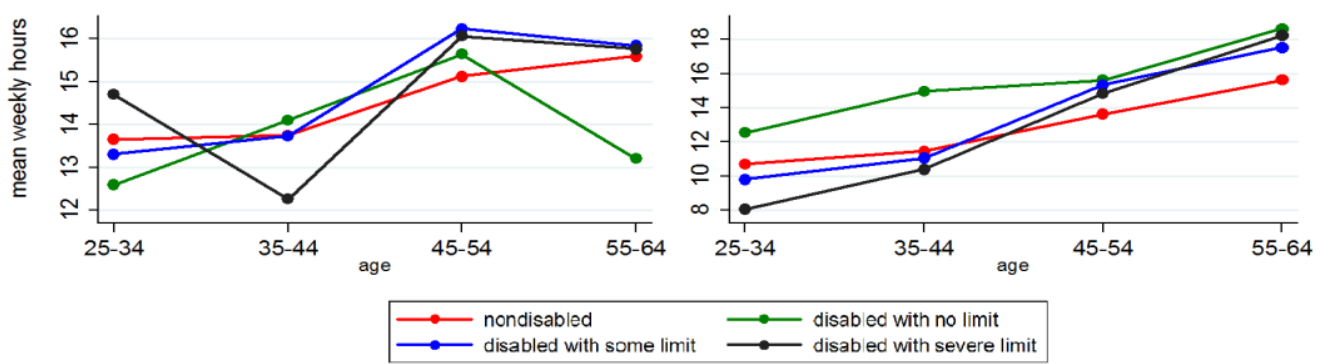

$\longrightarrow$ disabled with no limit disabed with severe limit

Figure 1. Distribution of Time According to Disability Status and Age

Notes: The sample is restricted to include non-student, non-retired individuals between the ages of 25 and 64. Sample weights are applied. Time use activities are measured as hours per week.

Source: TURKSTAT Time Use Survey 2014.

Table 1 shows the mean values of time devoted to market work, nonmarket work, leisure, childcare and other work in addition to mean values of explanatory variables according to gender and disability status. Disabled category in Table 1 includes disabled individuals with no limitations, disabled individuals with 
some limitations and disabled individuals with severe limitations in daily activities. The results of Table 1 can be summarized as the following: Firstly, the differences between disabled and nondisabled individuals in time devoted to market work, nonmarket work and leisure are significant at 5 percent level both for males and females. The difference is especially significant for disabled individuals in the time devoted to market work. Furthermore, this difference is higher for disabled males than disabled females. Secondly, differences in time devoted to childcare and other work are significant for females and insignificant for males. Thirdly, the share of disabled individuals increases with age and decreases with education and the differences in age and education are significant at 5 percent level. The findings of Table 1 imply that disabled individuals are unable to achieve as many hours of work as they like and they devote more time into other activities (Pagan, 2013). In other words, the results are in line with substitutability of time between market, nonmarket work and leisure and disability makes the substitutability even more profound.

Table 1. Mean Time Allocation and Mean Values of Explanatory Variables by Gender and Disability Status

\begin{tabular}{|c|c|c|c|c|c|c|}
\hline & \multicolumn{3}{|c|}{ Males } & \multicolumn{3}{|c|}{ Females } \\
\hline & nondisabled & $\overline{\text { disabled }}$ & difference & nondisabled & $\overline{\text { disabled }}$ & difference \\
\hline \multicolumn{7}{|l|}{ Time Use } \\
\hline market work & 43.98 & 30.29 & $13.69 *$ & 10.98 & 4.36 & $6.62 *$ \\
\hline nonmarket work & 4.08 & 5.37 & $-1.29 *$ & 32.35 & 30.82 & $1.53 *$ \\
\hline leisure & 103.99 & 116.37 & $-12.38 *$ & 107.03 & 113.66 & $-6.63 *$ \\
\hline childcare & 1.75 & 1.18 & 0.57 & 6.55 & 3.27 & $3.28 *$ \\
\hline otherwork & 14.19 & 14.76 & -0.57 & 12.07 & 14.87 & $-2.80 *$ \\
\hline \multicolumn{7}{|l|}{ Age } \\
\hline $25-34$ & 0.33 & 0.14 & $0.19 *$ & 0.35 & 0.08 & $0.27 *$ \\
\hline $35-44$ & 0.34 & 0.27 & $0.07 *$ & 0.34 & 0.25 & $0.09 *$ \\
\hline $45-54$ & 0.24 & 0.35 & $-0.11 *$ & 0.40 & 0.47 & $-0.07 *$ \\
\hline $55-64$ & 0.08 & 0.23 & $-0.15^{*}$ & 0.10 & 0.33 & $-0.23 *$ \\
\hline \multicolumn{7}{|l|}{ Marital status } \\
\hline single & 0.14 & 0.09 & $0.05^{*}$ & 0.08 & 0.03 & $0.05^{*}$ \\
\hline married & 0.82 & 0.88 & $-0.06 *$ & 0.85 & 0.83 & $0.02 *$ \\
\hline separated & 0.03 & 0.02 & 0.01 & 0.07 & 0.13 & $-0.06 *$ \\
\hline \multicolumn{7}{|l|}{ Education } \\
\hline no degree & 0.03 & 0.08 & $-0.06 *$ & 0.14 & 0.31 & $-0.17 *$ \\
\hline primary & 0.34 & 0.49 & $-0.15^{*}$ & 0.41 & 0.51 & $-0.10 *$ \\
\hline secondary & 0.14 & 0.14 & 0.01 & 0.10 & 0.06 & $0.04 *$ \\
\hline high school & 0.25 & 0.19 & $0.06^{*}$ & 0.17 & 0.06 & $0.11 *$ \\
\hline university & 0.23 & 0.09 & $0.14 *$ & 0.16 & 0.04 & $0.12 *$ \\
\hline \multicolumn{7}{|l|}{$\begin{array}{l}\text { Household } \\
\text { structure }\end{array}$} \\
\hline minor & 0.68 & 0.65 & $0.03 *$ & 0.69 & 0.52 & $0.17 *$ \\
\hline old care & 0.08 & 0.10 & -0.02 & 0.10 & 0.11 & -0.01 \\
\hline hh without head & 0.05 & 0.07 & $-0.02 *$ & 0.08 & 0.07 & $0.01 *$ \\
\hline vehicle & 0.50 & 0.41 & $0.09 *$ & 0.47 & 0.38 & $0.09 *$ \\
\hline Sample size & 4490 & 696 & & 4651 & 1440 & \\
\hline
\end{tabular}

Notes: The sample is restricted to include non-student, non-retired individuals between the ages of 25 and 64 . Sample weights are applied. Time use activities are measured as hours per week. *difference between nondisabled and disabled significant at 5\%. Source: TURKSTAT Time Use Survey 2014. 
Table 2 and Table 3 show SUR-OLS results for males and females respectively which are obtained from equations (1) to (5). Regarding results for men, significant negative association between time devoted market work and degree of disability status is observed. In terms of time devoted to market work, disabled males with severe limitations spend 21 hours less than their nondisabled counterparts in a week. On the other hand, time allocated to nonmarket work and leisure significantly increases with the degree of disability. Disabled males with severe limitations allocate 1.88 more hours to nonmarket work and 19.02 more hours to leisure on average than their nondisabled counterparts. The relationship between childcare and other work for males is mostly insignificant. Additionally, education seems to be an important correlating factor. There is a positive and significant association between time devoted to market work and education, and a negative and significant association between time allocated to nonmarket work, leisure and education. Among the variables that define household structure, only dummy variable for the existence of a vehicle in the household and dummy indicating the households without heads are significant for males.

Table 2. Estimates of Disability Status on Time Use Categories, Males

\begin{tabular}{|c|c|c|c|c|c|}
\hline & Market work & Nonmarket work & Leisure & Childcare & Other work \\
\hline \multicolumn{6}{|l|}{$\begin{array}{l}\text { Disability status } \\
\text { (reference:nondisabled) }\end{array}$} \\
\hline $\begin{array}{l}\text { disabled with no } \\
\text { limitations }\end{array}$ & $-6.64 * *(1.77)$ & $0.27(0.50)$ & $6.37 * *(1.58)$ & $0.23(0.26)$ & $-0.60(0.54)$ \\
\hline $\begin{array}{l}\text { disabled with some } \\
\text { limitations }\end{array}$ & $-11.2 * *(1.33)$ & $1.16^{* *(0.37)}$ & $9.65^{* *(1.19)}$ & $-0.10(0.20)$ & $0.48(0.41)$ \\
\hline $\begin{array}{l}\text { disabled with severe } \\
\text { limitations }\end{array}$ & $-21.79 * *(2.10)$ & $1.88 * *(0.59)$ & $19.02 * *(1.88)$ & $0.12(0.31)$ & $1.55 * *(0.64)$ \\
\hline \multicolumn{6}{|l|}{$\begin{array}{l}\text { Age } \\
\text { (reference: 25-34) }\end{array}$} \\
\hline $35-44$ & $0.66(0.89)$ & $0.37(0.25)$ & $1.09(0.80)$ & $-0.94 *(0.13)$ & $0.18(0.27)$ \\
\hline $45-54$ & $-4.47(0.97)$ & $0.94 * *(0.27)$ & $3.88 * *(0.87)$ & $-1.07 *(0.14)$ & $1.65 * *(0.29)$ \\
\hline $55-64$ & $-8.47 * *(1.34)$ & $2.08 * *(0.38)$ & $6.01 * *(1.21)$ & $-1.53 *(0.20)$ & $2.94 * *(0.41)$ \\
\hline \multicolumn{6}{|l|}{$\begin{array}{l}\text { Marital status } \\
\text { (reference: single) }\end{array}$} \\
\hline married & $5.49 * *(1.18)$ & $-0.36(0.33)$ & $-7.78 * *(1.06)$ & $2.02 *(0.17)$ & $0.31(0.36)$ \\
\hline separated & $2.16(2.29)$ & $2.97 * *(0.64)$ & $-4.96 * *(2.05)$ & $1.28 *(0.34)$ & $-0.66(0.70)$ \\
\hline \multicolumn{6}{|l|}{$\begin{array}{l}\text { Education } \\
\text { (reference: no degree) }\end{array}$} \\
\hline primary & $14.42 * *(1.77)$ & $-2.09 * *(0.50)$ & $-9.42 * *(1.59)$ & $-0.29(0.26)$ & $-3.30 * *(0.54)$ \\
\hline secondary & $16.15 * *(1.91)$ & $-1.97 * *(0.54)$ & $-11.37 * *(1.71)$ & $0.03(0.28)$ & $-3.34 * *(0.58)$ \\
\hline high school & $14.78 * *(1.83)$ & $-1.49 * *(0.52)$ & $-11.74 * *(1.65)$ & $0.46 *(0.27)$ & $-3.16 * *(0.56)$ \\
\hline university & $7.78 * *(1.88)$ & $-0.71(0.53)$ & $-8.53 * *(1.69)$ & $1.07 * *(0.28)$ & $-1.46^{* *}(0.57)$ \\
\hline $\begin{array}{l}\text { Household structure } \\
\text { minor in } \mathrm{h} h\end{array}$ & $1.35(0.82)$ & $-0.31(0.23)$ & $-2.65 * *(0.74)$ & $1.49 * *(0.12)$ & $0.19(0.25)$ \\
\hline old care & $-1.70(1.18)$ & $0.87 * *(0.33)$ & $-0.35(1.06)$ & $-0.13(0.17)$ & $0.71 * *(0.36)$ \\
\hline household hsize & $-0.47(0.46)$ & $-0.91 * *(0.13)$ & $1.37 * *(0.41)$ & $-0.19 * *(0.07)$ & $0.32 * *(0.14)$ \\
\hline vehicle in the $h h$ & $2.40 * *(0.70)$ & $0.42 * *(0.19)$ & $-2.18 * *(0.63)$ & $0.029(0.17)$ & $-0.36 *(0.21)$ \\
\hline hh without head & $-4.72 * *(1.46)$ & $0.90 * *(0.41)$ & $2.73 * *(1.31)$ & $-0.36 *(0.22)$ & $1.00 * *(0.45)$ \\
\hline R-squared & 0.091 & 0.043 & 0.091 & 0.125 & 0.039 \\
\hline Sample size & 5,186 & 5,186 & 5,186 & 5,186 & 5,186 \\
\hline
\end{tabular}

Notes: The sample is restricted to include non-student, non-retired individuals between the ages of 25 and 64 . Sample weights are applied. Time use activities are measured as hours per week. *significant at $10 \%$ level. **significant at $5 \%$ level. Heteroscedasticity consistent standard errors are in parenthesis. Source: TURKSTAT Time Use Survey 2014. 
Findings regarding females also show significant and negative association between disability status and time spent on market work which can be seen in Table 3. Disabled females with severe limitations spent 3.55 less hours in a week than their nondisabled counterparts for market work. Additionally, results present positive relationship between disability status and time devoted to leisure and other work. Disabled females with severe limitations devote 7.29 more hours to leisure and 1.29 more hours to other work than nondisabled females. In opposition to the results for males, negative and significant association between disability status and nonmarket work is observed for females. Furthermore, in opposition to results in Table 1, estimations results show that disability status and time allocated to childcare have no significant relationship. Age and education are important correlating factors in most of the specifications. For instance, time devoted to leisure and other work significantly rises with age, and time devoted to market work significantly increases with education. Existence of a minor/child and an old adult who needs care are also significant in most of the specifications in Table 3.

$\underline{\text { Table 3. Estimates of Disability Status on Time Use Categories, Females }}$

\begin{tabular}{|c|c|c|c|c|c|}
\hline & Market work & Nonmarket work & Leisure & Childcare & Other work \\
\hline \multicolumn{6}{|l|}{$\begin{array}{l}\text { Disability status } \\
\text { (reference:nondisabled) }\end{array}$} \\
\hline $\begin{array}{l}\text { disabled with no } \\
\text { limitations }\end{array}$ & $-1.64(1.02)$ & $-1.63 * *(0.81)$ & $1.34(1.02)$ & $-0.53(0.50)$ & $2.16 * *(0.56)$ \\
\hline $\begin{array}{l}\text { disabled with some } \\
\text { limitations }\end{array}$ & $-2.56^{* *}(0.70)$ & $-0.54(0.55)$ & $2.11 * *(0.70)$ & $0.18(0.34)$ & $1.05 * *(0.38)$ \\
\hline $\begin{array}{l}\text { disabled with severe } \\
\text { limitations }\end{array}$ & $-3.55^{* *}(1.10)$ & $-4.69 * *(0.88)$ & $7.29 * *(1.10)$ & $0.01(0.54)$ & $1.29 * *(0.60)$ \\
\hline \multicolumn{6}{|l|}{$\begin{array}{l}\text { Age } \\
\text { (reference: } 25-34 \text { ) }\end{array}$} \\
\hline $35-44$ & $3.75 * *(0.60)$ & $-0.22(0.47)$ & $1.97 * *(0.60)$ & $-6.16^{* *}(0.29)$ & $0.07(0.32)$ \\
\hline $45-54$ & $0.17(0.70)$ & $0.71(0.56)$ & $4.98 * *(0.70)$ & $-8.78 * *(0.34)$ & $2.74 * *(0.38)$ \\
\hline $55-64$ & $-3.88 * *(0.87)$ & $-1.77 * *(0.69)$ & $7.66 * *(0.87)$ & $-7.34 * *(0.42)$ & $5.67 * *(0.47)$ \\
\hline \multicolumn{6}{|l|}{$\begin{array}{l}\text { Marital status } \\
\text { (reference: single) }\end{array}$} \\
\hline married & $-7.20 * *(1.01)$ & $11.59 * *(0.80)$ & $-7.95 * *(1.01)$ & $7.52 * *(0.49)$ & $-1.30 * *(0.55)$ \\
\hline separated & $-2.87 * *(1.29)$ & $3.44 * *(1.02)$ & $-3.87 * *(1.29)$ & $6.23 * *(0.63)$ & $-2.29 * *(0.70)$ \\
\hline \multicolumn{6}{|l|}{$\begin{array}{l}\text { Education } \\
\text { (reference: no degree) }\end{array}$} \\
\hline primary & $3.18 * *(0.65)$ & $-1.77 * *(0.52)$ & $-2.90 * *(0.65)$ & $0.20(0.32)$ & $-0.67 *(0.35)$ \\
\hline secondary & $7.57 * *(0.93)$ & $-4.37 * *(0.74)$ & $-4.51 * *(0.93)$ & $0.95 * *(0.46)$ & $-2.25 * *(0.51)$ \\
\hline high school & $10.07 * *(0.84)$ & $-6.49 * *(0.67)$ & $-5.47 * *(0.84)$ & $2.07 * *(0.41)$ & $-3.61 * *(0.46)$ \\
\hline university & $18.25 * *(0.91)$ & $-13.90(0.72)$ & $-7.70 * *(0.91)$ & $1.90 * *(0.44)$ & $-3.76 * *(0.49)$ \\
\hline \multicolumn{6}{|l|}{ Household structure } \\
\hline minor in $h h$ & $-3.28 * *(0.56)$ & $0.81 *(0.45)$ & $-1.13 * *(0.56)$ & $4.51 * *(0.27)$ & $-0.77 * *(0.30)$ \\
\hline old care & $-2.25 * *(0.73)$ & $2.75 * *(0.58)$ & $-2.78 * *(0.73)$ & $-0.16(0.36)$ & $2.29 * *(0.40)$ \\
\hline household hsize & $0.25(0.31)$ & $-0.92 * *(0.25)$ & $1.24 * *(0.31)$ & $-0.25 *(0.15)$ & $-0.14(0.17)$ \\
\hline vehicle in the $h h$ & $-0.42(0.48)$ & $0.19(0.38)$ & $0.04(0.48)$ & $-0.04(0.23)$ & $0.19(0.26)$ \\
\hline hh without head & $-1.38(0.85)$ & $0.20(0.67)$ & $-0.62(0.84)$ & $-0.34(0.41)$ & $2.18 * *(0.46)$ \\
\hline R-squared & 0.17 & 0.17 & 0.09 & 0.24 & 0.11 \\
\hline Sample size & 6091 & 6091 & 6091 & 6091 & 6091 \\
\hline
\end{tabular}

Notes: The sample is restricted to include non-student, non-retired individuals between the ages of 25 and 64. Sample weights are applied. Time use activities are measured as hours per week. *significant at $10 \%$ level. **significant at $5 \%$ level. Heteroscedasticity consistent standard errors are in parenthesis. Source: TURKSTAT Time Use Survey 2014. 


\section{CONCLUSION}

This study examines the relationship between disability status and time allocated to daily activities by using TURKSTAT Time Use Survey 2014. Results can be summarized as follows: Males spend more time to market work and leisure, whereas females spend more time to nonmarket work, childcare and other work on average. Furthermore, significant differences between disabled and nondisabled individuals are observed in time devoted to market work and nonmarket work both for males and females. SUR-OLS results show significant and negative association between disability status and time devoted to market work, and significant and positive association between disability and time allocated to nonmarket work and leisure for males. On the other hand, relationship between disability and nonmarket work for females is negative. Further, age and education level are important correlating factors. Findings regarding males in this study are in line with Pagan (2013). However, results regarding females differs from the literature (Leufstadius and Erklund,2008; Lomax et al.,2004; Pagan,2013). Diversified results may stem from lower labor force participation rates of females in Turkey and the impact of social roles in different set of samples.

This study has some limitations. Firstly, the methodology adapted here is descriptive, the findings can only be interpreted as correlations. Secondly, data used is cross-section and it does not allow to observe effect of disability status net of individual heterogeneity in preferences. Thirdly, regional unemployment rates can be effective in determining time allocation decisions which are not available in data. Fourthly, individuals under 25 and over 64 are excluded from the sample due to intertemporal component of time allocation decisions and heterogeneity in time use preferences of this group. Although including individuals under 25 and over 64 is not directly in line with the aim of this paper, investigating young population (aged between 15-24) and/or retirees (aged over 64) in a different study would be interesting in terms of time allocation (especially in terms of time use in leisure and nonmarket work) decisions of these groups. For instance, examining the relationship between time allocation and disability status of young population (between 15 and 24 years of age) would reveal interesting patterns in terms of leisure and market work.

Despite the limitations of the study, findings will be interest of policy makers. Policies directed to ensure gender equality in terms of time allocated to labor market and to encourage disabled individuals participate in the labor force would increase the well-being of both females and disabled individuals. Public policies desired to achieve minimum level of public health coverage for disabled individuals and extent this coverage as much as possible could increase time allocated to market work for disabled individuals. In 2008 labor law has changed to increase the labor force participation of disabled individuals. Efficient implementation of labor law could be controlled by the policy makers. Another interesting finding of this study is that opposite movement of time devoted to market work and nonmarket work for both genders. Since nondisabled individuals have greater time use in market work than their disabled counterparts, this would lead more ability to outsource household activities via higher 
income which especially the case for females. The policy implication of this behavior could also open a new research area about the influence of disability status to nonmarket work and thus household production by considering gender differences. Additionally, time devoted to leisure with respect to disability status would also have interesting policy implications for future research. Policy makers would investigate welfare loss or gain in time devoted to leisure due to disability status. 


\section{REFERENCES}

Aguiar, M., \& Hurst, E. (2007). Measuring trends in leisure: the allocation of time over five decades. The Quarterly Journal of Economics. 122 (3), 969-1006. https://doi.org/10.1162/qjec.122.3.969

Aguiar, M., \& Hurst, E. (2008). The increase in leisure inequality. NBER Working Paper No.12837. https://doi.org/10.3386/w13837

Ali, M., Schur, L., \& Blanck, P. (2011). What types of jobs do people with disabilities want? Journal of Occupational Rehabilitation, 21, 199-210. https://doi.org/10.1007/s10926-010-9266-0

Baldwin, M., \& Johnson, W.G. (1994). Labor market discrimination against men with disabilities. Journal of Human Resources, 29(1), 1-19. https://doi.org/10.2307/146053

Cai, L., Mavromaras, K., \& Oguzoglu, U. (2014). The effects of health status and health shocks on hours worked. Health Economics. 23 (5), 516-528. https://doi.org/10.1002/hec.2931

Duzgun-Oncel, B., \& Karaoglan, D. (2020). Disability and labor force participation in a developing country: evidence from turkish males. Global Business and Economics Review, 22(3), 270-288. https://doi.org/10.1504/GBER.2020.106245

Gannon, B. (2009). The influence of economic incentives on reported disability status. Health Economics. 18, 743-759. https://doi.org/10.1002/hec.1399

Gimenez-Nadal, J.I., \& Ortega-Lapiedra, R. (2013). Health status and time allocation in spain. Applied Economics Letters. 20 (15), 1435-1439. https://doi.org/10.1080/13504851.2013.818205

Gimenez-Nadal, J.I., \& Molina, J. A. (2014). Regional unemployment, gender, and time allocation of the unemployed. Review of Economics of the Household. 12, 105-127. https://doi.org/ 10.1007/s11150-013-9186-9

Gimenez-Nadal, J.I., \& Molina, J. A. (2015). Health status and the allocation of time: cross-country evidence from europe. Economic Modelling. 46, 188-203. https://doi.org/10.1016/j.econmod.2014.12.034

Kidd, M.P., Sloane, P.J., \& Ferko, I. (2000). Disability and labor market: an analysis of british males. Journal of Health Economics. 19, 961-981. https://doi.org/10.1016/S0167-6296(00)00043-6

Leufstadius, C., \& Eklund, M. (2008). Time use among individuals with persistent mental illness: identifying risk factors for imbalance in daily activities. Scandinavian Journal of Occupational Therapy. 15, 23-33. https://doi.org/10.3109/11038128.2014.952905

Lindeboom, M., Llena-Nozal, A., \& Van der Klaauw, B. (2016). Health shocks, disability and work. Labour Economics. 43, 186-200. https://doi.org/10.1016/j.labeco.2016.06.010

Lomax, C., Brown, R., \& Howard, R. (2004). Measuring disability in patients with neurodegenerative disease using the yesterday interview. International Journal of Geriatric Psychiatry. 19, 1058-1064. https://doi.org/10.1002/gps.1210

Oi, W. (1991). Disability and work, In Caroline Weaver (Ed.), Disability and a Workfare-Welfare Dilemma. Washington: AEI Press.

Ozturk, Y., \& Kose, T. (2019). Health, time allocation and work: empirical evidence from turkey. Applied Economics. 51, 5609-5622. https://doi.org/10.1080/00036846.2019.1616070

Pagan, R. (2013). Time allocation of disabled individuals. Social Science and Medicine. 84, 80-93. https://doi.org/10.1016/j.socscimed.2013.02.014

Podor, M., \& Halliday, T. J. (2012). Health status and the allocation of time. Health Economics. 21, 514-527. https://doi.org/10.1002/hec.1725 
Schuring, M., Robroek, S.T.W., Otten, F. W. J., Arts, C. H., \& Burdorf, A. (2013). The effect of ill health and socioeconomic status on labor force exit and re-employment: a prospective study with ten years of follow-up in the netherlands. Scandinavian Journal of Work, Environment \& Health. 39(2), 134-143. https://doi.org/10.5271/sjweh.3321

Turkish Statistical Institute (TURKSTAT) 2021. Time Use Survey 2014, January 2020.

Vornholt, K., Villotti, P., Muschalla, B., Bauer, J., Colella, A., Zijlstra, F., Van Ruitenbeek, G., Uitdewilligen, S., \& Corbiere, M. (2017). Disability and employment: overview and highlights. European Journal of Work and Organizational Psychology. 27(1), 40-55. https://doi.org/10.1080/1359432X.2017.1387536

World Health Organization, 2021.

https://www.who.int/news-room/fact-sheets/detail/disability-and- health. (Accessed $18^{\text {th }}$ of January 2021). 